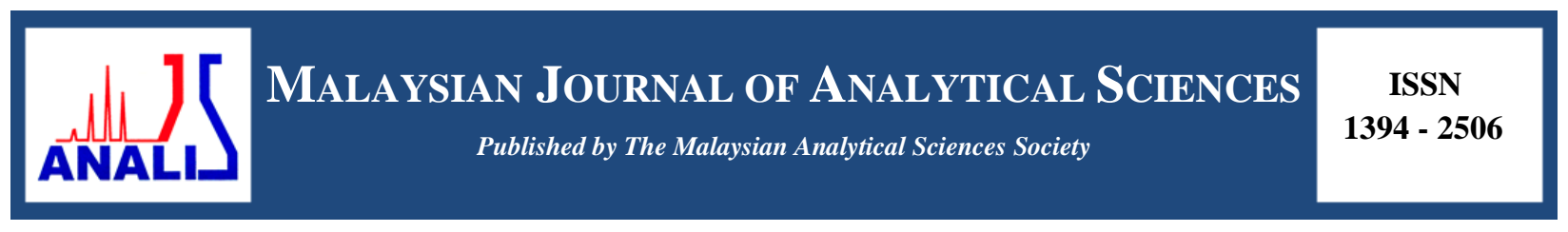

\title{
DETERMINATION OF PRAZOSIN AND SIMVASTATIN IN LANDFILL LEACHATE USING LIQUID CHROMATOGRAPHY-TIME OF FLIGHT- MASS SPECTROMETRY
}

\author{
(Penentuan Prazosin dan Simvastatin di dalam Larut Lesap Mengunakan Kromatografi Cecair- \\ Masa Penerbangan-Spektrometri Jisim) \\ Zainab Haider Mussa ${ }^{1,2}$, Fouad Fadhil Al-Qaim ${ }^{1,3}$, Md Pauzi Abdullah ${ }^{1,4}$, Mohamed Rozali Othman ${ }^{1,4}$

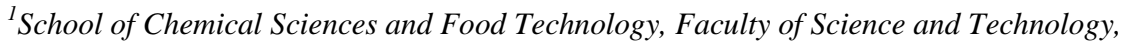 \\ Universiti Kebangsaan Malaysia, 43600 UKM Bangi, Selangor, Malaysia \\ ${ }^{2}$ Faculty of Pharmacy \\ ${ }^{3}$ Department of Chemistry, Faculty of Sciences for Women \\ University of Babylon, PO Box 4, Hilla, Iraq \\ ${ }^{4}$ Centre for Water Research and Analysis (ALIR), Faculty of Science and Technology, \\ Universiti Kebangsaan Malaysia, 43600 UKM Bangi, Selangor, Malaysia \\ *Corresponding author: fouadalkaim@yahoo.com
}

Received: 13 January 2016; Accepted: 27 March 2016

\begin{abstract}
Human pharmaceuticals have been shown to occur in considerably high amounts in sewage treatment plant (STP) effluents and surface waters. So far there is no data available on the occurrence of prazosin and simvastatin in leachate sample in Malaysia. Thus, this study is the first report to analysis of prazosin and simvastatin in leachate samples by using solid phase extractionliquid chromatography-time of flight-mass spectrometry (SPE-LC-TOF-MS). The proposed method included isolation and reconstitute procedure. The linearity range was achieved at $1.5-3000 \mu \mathrm{g} / \mathrm{L}$ and $0.8-125 \mu \mathrm{g} / \mathrm{L}$ for prazosin and simvstatin, respectively with a determination coefficient $\left(R^{2}\right)>0.99$. The limit of quantification (LOQ) for prazosin and simvastatin was calculated at 2.1 and $0.5 \mathrm{ng} / \mathrm{L}$ in deionised water (DIW), meanwhile it was recorded at 3.5 and $2.4 \mathrm{ng} / \mathrm{L}$ for prazosin and simvastatin in effluent sample, respectively. Two pharmaceutical compounds were detected in the leachate samples: prazosin and simvastatin at concentrations levels of 3850 and $415 \mathrm{ng} / \mathrm{L}$, respectively.
\end{abstract}

Keywords: prazosin, simvastatin, leachate, solid phase extraction, pharmaceutical pollution

\begin{abstract}
Abstrak
Farmaseutikal manusia telah hadir di dalam effluen loji sisa rawatan dan air permukaan. Sehingga kini, tiada data kajian yang merekodkan kehadiran prazosin dan simvastatin dalam sampel larut lesap di Malaysia. Maka, kajian ini merupakan laporan pertama tentang analisis terhadap prazosin dan simvastatin di dalam sampel larut lesap mengunakan pengekstrakan fasa pepejalkromatografi cecair-masa penerbangan-spekrometri jisim (SPE-LC-TOF-MS). Kaedah yang dibangun meliputi langkah pemisahan dan nilai isian semula. Julat kelinearan dicapai antara $1.5-3000 \mu \mathrm{g} / \mathrm{L}$ dan $0.8-125 \mu \mathrm{g} / \mathrm{L}$ masing - masing bagi prazosin dan simvastatin dengan nilai pekali $\left(\mathrm{R}^{2}\right)>0.99$. Had kuantifikasi (LOQ) bagi prazosin and simvastatin dihitung pada aras 2.1 dan $0.5 \mathrm{ng} / \mathrm{L}$ di dalam air ternyahion manakala direkod masing-masing pada aras 3.5 dan $2.4 \mathrm{ng} / \mathrm{L}$ di dalam sampel efluen. Dua jenis sebatian farmaseutikal ini dikesan in dalam sampel larut lesap pada aras kepekatan masing-masing adalah 3850 and $415 \mathrm{ng} / \mathrm{L}$.
\end{abstract}

Kata kunci: prazosin, simvastatin, larut lesap, pengekstrakan fasa pepejal, pencemaran farmaseutikal 


\section{Introduction}

The occurrence of pharmaceutical in the aquatic environment has been recognized as one of the emerging issues in environmental chemistry. The widespread presence in the aquatic environment can be explained by their extensive use in medical practice and incomplete removal in wastewater treatment plants (WWTPs) [1]. These compounds present in the environment at trace levels $(\mathrm{ng} / \mathrm{L}-\mu \mathrm{g} / \mathrm{L})$, hence it is known as micro pollutants. For this reason, in the past century, their detection was infeasible due to lack of sophisticated analytical technique. In recent years, advancements in analytical methods have contributed to the detection of over 100 active agents in pharmaceutical products in different environmental matrices [2,3]. Scientific research studies conducted in Malaysia and worldwide have reported widespread occurrence of pharmaceuticals in surface water, influent and effluent sewage treatment plants and hospitals [4 -7]. The reason may related to several ways which are participated to introduce the pharmaceuticals to surface water such as insufficiently treated sewage effluents, production residues, improper disposal of expired medications and unused drugs and accidental spillage during manufacturing and distribution [8].

In leachate samples, the detection of pharmaceuticals has never been studied except few reported papers [9, 10]. Landfills may be sources of a large number of organic compounds known as emerging contaminants (ECs and/or EDCs) such as pharmaceuticals, pesticides, fertilizers and others. Pharmaceutical compounds may occur in concentration of approximately $8.1 \mathrm{mg} / \mathrm{kg}$ in typical municipal solid waste. In landfills, these compounds may be degraded/metabolized, adsorbed to solids or dissolved in leachate. Release of these chemicals in the environment may affect public health on humans, animals and ecosystem.

Liquid chromatography - tandem mass spectrometry [LC-MS/MS] is one of the most popular analytical methods used to analyse pharmaceutical residues in water samples due to its versatility, specificity and selectivity. Other different approaches have been tried, including gas chromatography-mass spectrometry (GC-MS), voltammetry, potentiometry and LC-Uv as reviewed in previous studies [11, 12]. In Malaysia, simvastatin has been detected less than limit of detection (LOD) [13] while in Canada; it has been detected in $0.001 \mu \mathrm{g} / \mathrm{L}$ [14]. The differences in concentrations of simvastatin in treated wastewaters between different countries generally reflect different usage patterns, per-capita water consumption, and treatment processes.

The aim of this study is to determine the amount of prazosin and simvastatin in raw leachate, post-biological and post-charcoal adsorption treatment using liquid chromatography-time of flight/mass spectrometry.

\section{Materials and Methods}

Prazosin (PRZ) (CAS no.19237-84-4), simvastatin (SMV) (CAS no. 79902-63-9) were obtained from SigmaAldrich (USA). Figure 1 shows the chemical structure of these pharmaceuticals with molecular weight. Deionized water (DIW) used was supplied by EASYPure RODI (USA). Acetone, acetonitrile and methanol (HPLC grade) were purchased from Sigma-Aldrich (USA). Formic acid (FA) was supplied by Merck (Germany). Methyl Tertiary Butyl Ether (MTBE) was supplied by J. T. Baker (USA). The cartridges used for solid phase extraction (SPE) were (Oasis HLB $3 \mathrm{~cm}^{3}, 60 \mathrm{mg}$ purchased from Waters (USA).

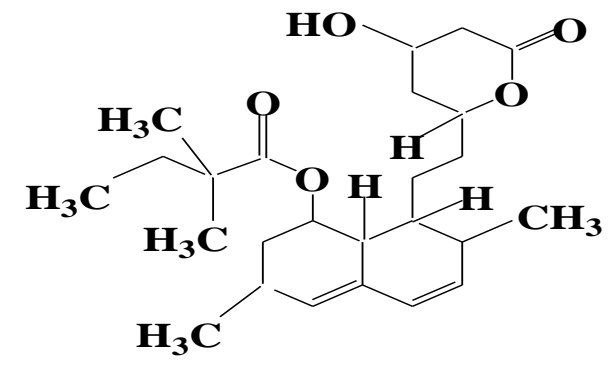

Simvastatin (SMV), $418 \mathrm{~g} / \mathrm{mol}$

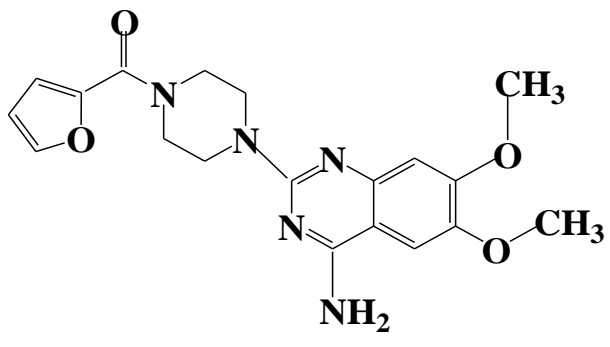

Prazosin (PRZ), $383 \mathrm{~g} / \mathrm{mol}$

Figure 1. Chemical structures of the studied compounds 


\section{Site description and sampling activities}

The leachate samples namely raw, biological and physico-chemical treated samples used in this study were collected from Jeram sanitary landfill leachate. Jeram sanitary landfill leachate is located in an oil palm plantation near Kuala Selangor Malaysia as shown in Figure 2. It is roughly rectangle in shape and occupied 64.7 hectares. Jeram sanitary landfill has been in operation by Worldwide Holdings since January 2007. This landfill is designed with a capacity to hold 6 million tons of waste. Currently, approximately 2000 tons of solid waste is disposed of at the landfill every day, and to date 4.1 million tons of waste has been added to the landfill [15].

All samples were collected in $1 \mathrm{~L}$ amber glass bottles with Teflon lined caps to ensure sample integrity using a stain steel bucket previously rinsed with distilled water and methanol. The bottles head spaces were kept to a minimum by filling the bottles to the top. The bottles were rinsed once with sample and filled to the top on the second sampling. Disposable gloves were used to prevent any personal care products from contaminating the sample bottles, then immediately transported to the laboratory. Samples were filtered through a $0.7 \mu \mathrm{m} \mathrm{GF} / \mathrm{G}$ filter from Whatman (UK) to remove suspended solids and stored at $4{ }^{\circ} \mathrm{C}$ in order to keep the wastewater characteristics unchanged.

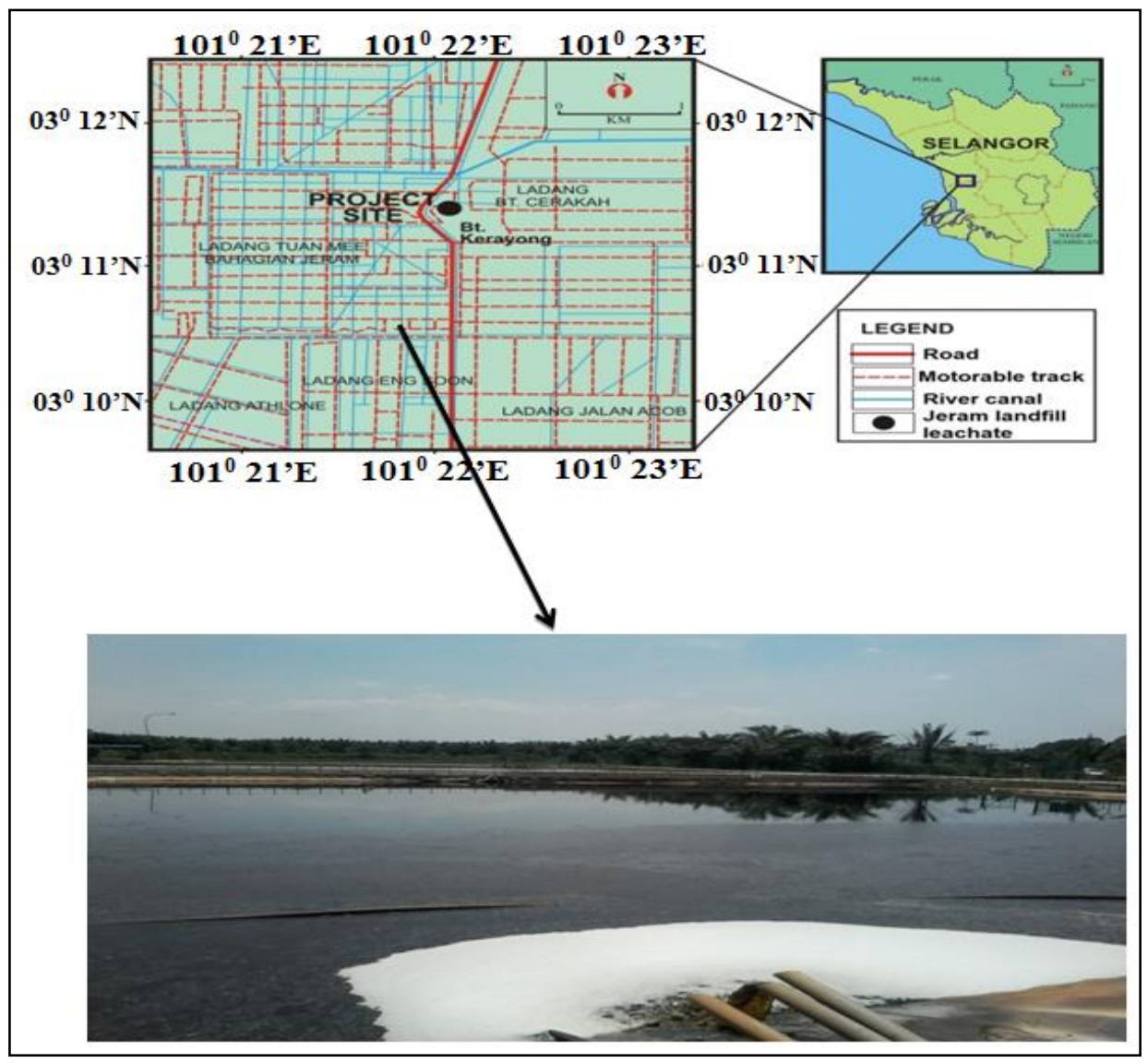

Figure 2. Map to describe location area 


\section{Method extraction of Prazosin and Simvastatin}

Solid phase extraction procedure used in this study has been described in our previous paper [7]. In summary, the Oasis HLB cartridges $\left(3 \mathrm{~cm}^{3}, 60 \mathrm{mg}\right)$ were preconditioned with $2 \mathrm{~mL}$ MTBE, $2 \mathrm{~mL}$ of $\mathrm{MeOH}$ and $2 \mathrm{~mL}$ of deionized water at a flow rate of $1 \mathrm{~mL} / \mathrm{min}$. After the conditioning step, an aliquot of $250 \mathrm{~mL}$ of sample (after biological and charcoal treatment) were loaded into the cartridge. In case of raw leachate, $10 \mathrm{~mL}$ was diluted to 250 $\mathrm{mL}$ with deionised water because of its high complexity. Samples were passed through the cartridges at a flow rate of $9.0 \mathrm{~mL} / \mathrm{min}$ and then, rinsed with $2 \mathrm{~mL}$ of deionized water prior to elution. After that, the cartridges were vacuum dried for $25 \mathrm{~min}$ to remove excess water. The pharmaceutical compounds were subsequently eluted into $12 \mathrm{~mL}$ glass tubes by sequentially passing $5 \times 1 \mathrm{~mL}$ MTBE, $2 \times 1 \mathrm{~mL}$ acetone-MeOH $(21: 9$, v/v), and $3 \times 1 \mathrm{~mL}$ acetone$\mathrm{MeOH}(9: 21, \mathrm{v} / \mathrm{v})$. The combined eluents were evaporated to dryness under a gentle stream of $\mathrm{N}_{2}$ gas. Dry extracts were reconstituted with $500 \mu \mathrm{L} \mathrm{MeOH-DIW} \mathrm{(10:90,} \mathrm{v/v)} \mathrm{and} \mathrm{then} \mathrm{transferred} \mathrm{to} 250 \mu \mathrm{L}$ deactivated glass insert with polymer feet inserted in amber glass vials from Agilent Technologies (USA). The extract (30 $\mu \mathrm{L})$ was automatically injected into LC-ESI-TOF/MS system for analysis.

The LC analysis was performed using a Dionex Ultimate 3000/LC 09115047 (USA) system equipped with a vacuum degasser, a quaternary pump, an auto sampler and a UV-Vis diode array detector. Chromatography was performed on a Thermo Scientific C18 $(250 \mathrm{~mm} \times 2.1 \mathrm{~mm}$, i.d.: $5 \mu \mathrm{m})$ column. The injection volume was $30 \mu \mathrm{L}$. Simvastatin and prazosin were analysed in positive ion (PI) mode and eluted off from the column using mobile phase consisting of (A) $0.1 \%$ FA in DIW and (B) ACN-MeOH (3:1, v/v) at $0.3 \mathrm{~mL} / \mathrm{min}$. The elution started at $5 \%$ $\mathrm{B}$ and was then linearly increased to $60 \% \mathrm{~B}$ over $3 \mathrm{~min}$, further increased to $97 \% \mathrm{~B}$ for $3 \mathrm{~min}$ and then kept isocratic for $5 \mathrm{~min}$. Next, the elution was returned to its starting conditions over $11.1 \mathrm{~min}$ and allowed to equilibrate for $5 \mathrm{~min}$ prior to the next run.

The mass spectrometry was carried out on a TOF instrument (Bruker/Germany) equipped with a Z-spray electrospray interface. The results were obtained with the following settings: MS capillary voltages, 4000/3500 (PI/NI); collision energy for prazosin and simvastatin, $10 \mathrm{eV}$; drying-gas flow rate, $8.0 \mathrm{~L} / \mathrm{min}$; drying gas temperature, $190^{\circ} \mathrm{C}$; set capillary, $4000 \mathrm{~V}$; set end plate offset $-500 \mathrm{~V}$; set collision cell RF, $250 \mathrm{Vpp}$ and nebuliser pressure, 4.0 bar. Two adduct ions, namely $[\mathrm{M}+\mathrm{H}]^{+}$for prazosin and $[\mathrm{M}+\mathrm{Na}]^{+}$for simvastatin, were observed using TOF/MS analysis in positive-ion mode. The TOF results were collected between $\mathrm{m} / z 50-600$. All analytes were acquired using an independent reference spray via the LockSpray interference to ensure accuracy and reproducibility; mixture of sodium hydroxide and formic acid was used as the lock mass $\mathrm{m} / \mathrm{z}$ 90.9766 - 974.8132. The accurate mass was calculated using software Daltonic Analysis incorporated in the instrument.

\section{Quality control}

Recoveries of the studied pharmaceuticals were determined by initially spiking the samples with a standard mixture of prazosin and simvastatin $(10 \mu \mathrm{g} / \mathrm{L})$. Six replicates of samples were then enriched using Oasis HLB SPE. Instrumental quantification limits (IQLs) are defined as the lowest concentration with a signal to noise ratio (S/N) of 10. This parameter was estimated by analyzing the standard of decreasing concentration. The LOQ was calculated based on the level of IQLs spiked in each compound using Equation (1), as reported by Vieno et al. [16].

$$
L O Q=\frac{I Q L \times 100}{\operatorname{Rec}(\%) \times C F}
$$

where IQL is the instrumental quantification limit (ng/L), Recovery $(\%)$ is the absolute recovery of the analyte at the IQL spiking level in the corresponding matrix, and $C F$ is the concentration factor (1000).

Selectivity of the proposed method was investigated by analyzing the chromatograms obtained from the individual standards, standard mixture, and solvent. Robustness of the method was studied by changing the flow rate of mobile phases $(0.29-0.31 \mathrm{~mL} / \mathrm{min})$, location of instrument (Lab1 and Lab2), and volume of injection $(10-40 \mu \mathrm{L})$.

\section{Quality control analysis}

\section{Results and Discussion}

Table 1 shows the linearity, limit of quantification (LOQ), instrumental quantification limit and recovery of prazosin and simvastatin obtained using the developed method. 
Table 1. Method validation parameters

\begin{tabular}{llcccccc}
\hline Compound & $\begin{array}{l}\text { Linearity } \\
\text { Range }(\boldsymbol{\mu g} / \mathbf{L})\end{array}$ & Equation & $\mathbf{R}^{\mathbf{2}}$ & $\begin{array}{c}\mathbf{I Q L} \\
(\boldsymbol{\mu g} / \mathbf{L})\end{array}$ & $\begin{array}{c}\mathbf{L O Q}^{\mathbf{a}} \\
\mathbf{n g} / \mathbf{L}\end{array}$ & $\begin{array}{c}\mathbf{L O Q}^{\mathbf{b}} \\
\mathbf{n g} / \mathbf{L}\end{array}$ & $\mathbf{R}^{\mathbf{c}}$ \\
\hline $\mathrm{PRZ}$ & $1.5-3000$ & $\mathrm{Y}=2311.4 \mathrm{X}-2485$ & 0.999 & 1.5 & 2.1 & 3.5 & 66 \\
$\mathrm{SMV}$ & $0.8-125$ & $\mathrm{Y}=14930.1 \mathrm{X}-49270$ & 0.997 & 0.8 & 0.5 & 2.4 & 62 \\
\hline
\end{tabular}

${ }^{\mathrm{a}}$ Deionized water, ${ }^{\mathrm{b}}$ STP effluent, ${ }^{\mathrm{c}}$ Recovery using STP effluent

It was observed that same retention time was obtained under all the conditions, indicating that the method was robust (Table 2). Thus, it was reliable to perform for analysis of real samples especially high complexity such as leachate samples.

Table 2. Effect of injection volume, lab movement and mobile phase on the robustness of LC method

\begin{tabular}{lccc}
\hline Figure of Merit & Value & PRZ & SMV \\
\hline Volume injection $(\mu \mathrm{L})$ & $10 \mu \mathrm{L}$ & 6.95 & 11.57 \\
& $20 \mu \mathrm{L}$ & 6.97 & 11.58 \\
& $30 \mu \mathrm{L}$ & 6.96 & 11.56 \\
& $40 \mu \mathrm{L}$ & 6.95 & 11.58 \\
Instrument place & $\mathrm{Lab} 1$ & 6.95 & 11.59 \\
& $\mathrm{Lab} 2$ & 6.93 & 11.57 \\
Flow rate $(\mathrm{mL} / \mathrm{min})$ & 0.29 & 7.11 & 11.87 \\
& 0.30 & 6.94 & 11.58 \\
& 0.31 & 6.76 & 11.29 \\
& $\mathrm{Mean}$ & 6.95 & 11.58 \\
& $\mathrm{SD}$ & 0.09 & 0.15 \\
& $\mathrm{RSD} \%$ & 1.3 & 1.4 \\
\hline
\end{tabular}

Lab 1 and Lab 2: Instrument has been moved from place to place.

\section{TOF screening and confirmation}

Measuring environmental contaminants in complex matrices is difficult because the analyte signals can be altered by interferences that are present in the real sample together with analytes. To increase the selectivity of TOF measurements, a narrow accurate mass interval was used to reconstruct the chromatographic traces. Extracted ion chromatograms (XICs) were typically extracted using a $20 \mathrm{mDa}$ mass window for prazosin and simvastatin (Figure $3)$. 

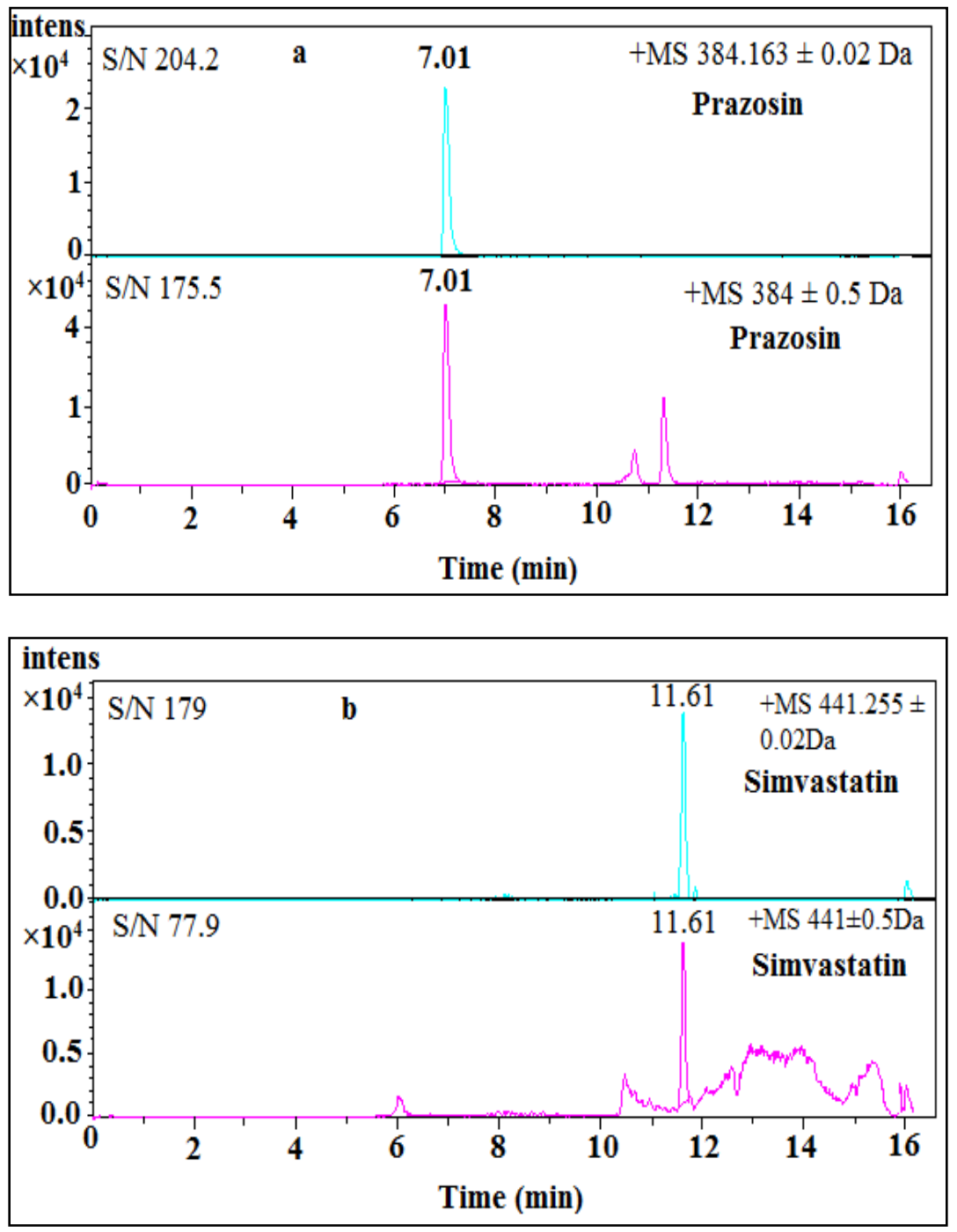

Figure 3. Enhanced selectivity of the LC-TOF/MS analysis corresponding to reconstruct ion chromatogram of (a) prazosin $(\mathrm{m} / \mathrm{z} 384)$ and (b) simvastatin $(\mathrm{m} / \mathrm{z} 441)$ in leachate sample with varying mass windows

Accurate mass data for the molecular ions were processed using Bruker Daltonics Data Analysis software, which provided the elemental formula and mass errors (i.e. differences between the accurate masses and the theoretical values), prazosin was selected as an example (Figure 4). The exact mass measurements and mass errors obtained in the TOF mode for molecular ions are listed in Table 3. The errors obtained were 1.56 and $0.2 \mathrm{ppm}$ for prazosin and simvastatin, respectively.

\section{Analysis of prazosin and simvastatin in real samples}

The proposed method was applied to real samples to determine prazosin and simvastatin in raw leachate, postbiological and post-charcoal adsorption treatment leachate. Prazosin and simvastatin were detected and quantified in the raw leachate and treated leachate. Prazosin was commonly used for treatment of hypertension, symptomatic benign prostatic hyperplasia, and severe congestive heart failure [17]. It was detected in surface water and wastewater in the previous study conducted by Al-Qaim et al. [5]. In this study, prazosin was found in raw leachate at relatively high concentration $3850 \mathrm{ng} / \mathrm{L}$ while it was detected in leachate samples after biological and charcoal 
treatment at concentration 98 and $94 \mathrm{ng} / \mathrm{L}$, respectively which is observed less concentration compared with raw leachate 40 fold-times. It showed that prazosin was persistent as it can be detected after treatment even at low concentration as shown in Figure 5.

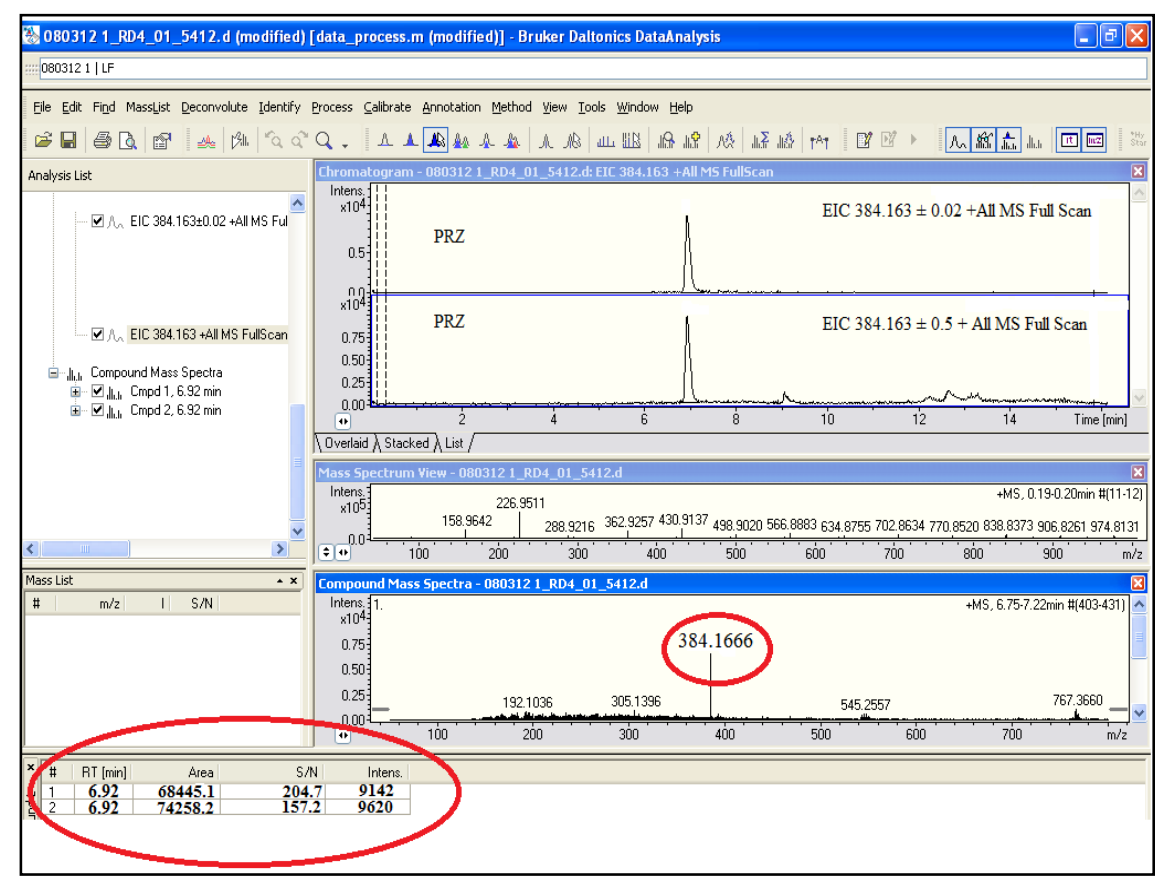

Figure 4. Daltonic data analysis software of prazosin

Table 3. Retention times and accurate mass measurements of molecular ions of target compounds in a standard solution

\begin{tabular}{|c|c|c|c|c|c|c|c|}
\hline \multirow{2}{*}{$\begin{array}{l}\text { Peak } \\
\text { No. }\end{array}$} & \multirow[t]{2}{*}{ Compound } & \multirow{2}{*}{$\begin{array}{l}\text { Ret. } \\
\text { (min) }\end{array}$} & \multirow{2}{*}{$\begin{array}{l}\text { Elemental } \\
\text { Composition }\end{array}$} & \multirow{2}{*}{$\begin{array}{c}\text { Experimental } \\
\text { Mass }(m / z)\end{array}$} & \multirow{2}{*}{$\begin{array}{l}\text { Theoretical } \\
\text { Mass }(m / z)\end{array}$} & \multicolumn{2}{|c|}{ Error } \\
\hline & & & & & & (mDa) & (ppm) \\
\hline 1 & PRZ & 6.95 & $\begin{array}{l}{[\mathrm{M}+\mathrm{H}]^{+}} \\
\mathrm{C}_{19} \mathrm{H}_{22} \mathrm{~N}_{5} \mathrm{O}_{4}\end{array}$ & 384.1660 & 384.1666 & 0.6 & 1.56 \\
\hline 2 & SMV & 11.59 & $\begin{array}{l}{[\mathrm{M}+\mathrm{Na}]^{+}} \\
\mathrm{C}_{25} \mathrm{H}_{38} \mathrm{NaO}_{5}\end{array}$ & 441.2611 & 441.2612 & 0.1 & 0.2 \\
\hline
\end{tabular}

Simvastatin being used in the treatment of primary hypercholesterolemia and it is effective in reducing total and LDL-cholesterol as well as plasma triglycerides and apolipoprotein B [17]. Previously, it was detected in surface water, effluent sewage treatment plants and hospital in Malaysia [7]. Finding study indicates that high concentration of simvastatin $(415 \mathrm{ng} / \mathrm{L})$ was detected in raw leachate sample. Other compartment such as biological and physicochemical (charcoal adsorption) treatments were able to reduce the concentration of samvastatin to 12 and $10.4 \mathrm{ng} / \mathrm{L}$, respectively. However, detection of simvastatin and prazosin in raw leachate may be due to disposal direct of these compounds as a solid form. In the light of these results, the biological and charcoal adsorption treatment processes are insufficient to remove these two compounds as they were detected in treated leachate as well as surface water. 

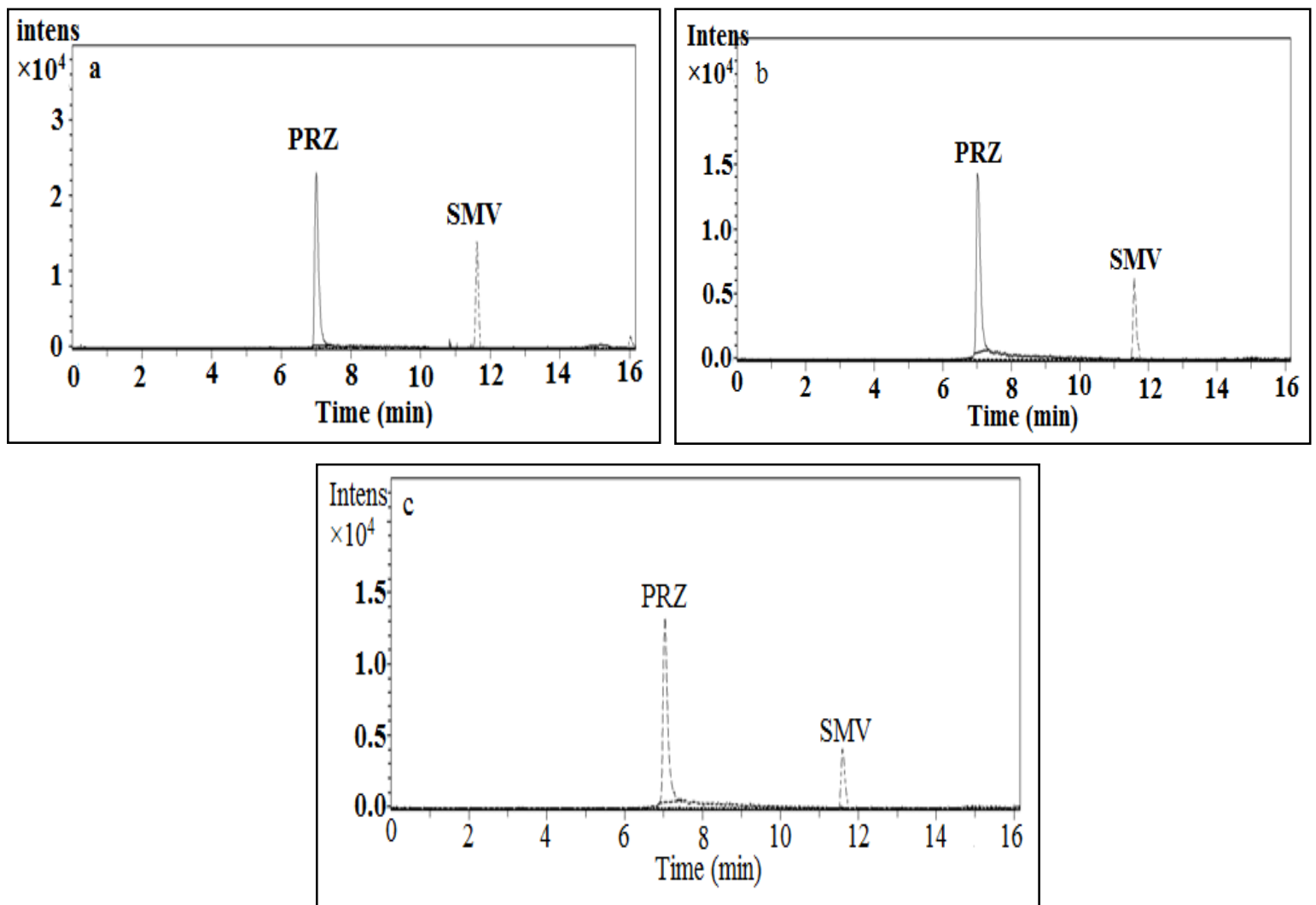

Figure 5. Extracted ionic chromatogram (EIC in PI mode) for prazosin and simvastatin in (a) raw leachate, (b) sample leachate post biological treatment and (c) sample leachate post charcoal adsorption.

\section{Conclusion}

The occurrence of prazosin and simvastatin in the leachate after biological and physico-chemical treatments showed that the difficulties are involved in treating this type of samples. Prazosin was persistent compounds as it can be detected after treatment even at low concentration. The detection of trace amounts of prazosin and simvastatin in complex sample indicated that LC-TOF/MS instrument is a powerful technique and very accurate for the analysis pharmaceuticals in water samples.

\section{Acknowledgement}

The authors thank Mr. Alefee for providing the LC-TOF/MS facilities to perform this study and the ALIR staff for providing ultra-pure water and facilities for leachate sampling. Special thanks to the staff of Jeram sanitary landfill company for given the permission in collecting leachate samples. This work was financially supported by UKMDLP-2012-024, UKM-AP-2011-21, BKP-FST-K001671 and FRGS-1-2013-ST01-UKM-01-1.

\section{References}

1. Moldovan, Z. (2006). Occurrences of pharmaceutical and personal care products as micropollutants in rivers from Romania. Chemosphere, 64 (11): 1808 - 1817.

2. Koreje, K. O., Demeestere, K., Wispelaere, P., Vergeynst, L., Dewulf, J. and Langenhove, H. V. (2012). From multi-residue screening to target analysis of pharmaceuticals in water: Development of a new approach based on magnetic sector mass spectrometry and application in the Nairobi river basin, Kenya. Science of the Total Environment, 437: 153 - 164. 
3. Petrović, M., Škrbić, B., Živančev, J., Ferrando-Climent, L. and Barcelo, D. (2014). Determination of 81 pharmaceutical drugs by high performance liquid chromatography coupled to mass spectrometry with hybrid triple quadrupole-linear ion trap in different types of water in Serbia. Science of the Total Environment, 468469: $415-428$.

4. Al-Odaini, N. A., Zakaria, M. P., Yaziz, M. I., Surif, S. and Abdulghani, M. (2013). The occurrence of human pharmaceuticals in wastewater effluents and surface water of Langat river and its tributaries, Malaysia. International Journal of Environmental Analytical Chemistry, 93 (3): 245 - 264.

5. Al-Qaim, F. F., Abdullah, M. P., Othman, M. R., Latip, J. and Afiq, W. M. (2013). Development of analytical method for detection of some pharmaceuticals in surface water. Tropical Journal of Pharmaceutical Research, 12 (4): $609-616$.

6. Al-Qaim, F. F., Abdullah, M. P., Othman, M. R., Latip, J. and Afiq, W. (2014). A validation method development for simultaneous LC-ESI-TOF/MS analysis of some pharmaceuticals in Tangkas river-Malaysia. Journal of the Brazilian Chemical Society, 25 (2): 271 - 281.

7. Al-Qaim, F. F., Abdullah, M. P., Othman, M. R., Latip, J. and Zakaria, Z. (2014b). Multi-residue analytical methodology-based liquid chromatography-time-of-flight-mass spectrometry for the analysis of pharmaceutical residues in surface water and effluents from sewage treatment plants and hospitals. Journal of Chromatography A, 1345: $139-153$.

8. Gómez, M. J., Petrović, M., Fernández-Alba, A. R. and Barceló, D. (2006). Determination of pharmaceuticals of various therapeutic classes by solid-phase extraction and liquid chromatography-tandem mass spectrometry analysis in hospital effluent wastewaters. Journal of Chromatography A, 1114 (2): $224-233$.

9. Joseph, L., Zaib, Q., Khan, I. A., Berge, N. D., Park, Y. G., Saleh, N. B. and Yoon, Y. (2011). Removal of bisphenol A and 17 $\alpha$-ethinyl estradiol from landfill leachate using single-walled carbon nanotubes. Water Research, 45 (13): 4056 - 4068.

10. Andrews, W. J., Masoner, J. R. and Cozzarelli, I. M. (2012). Emerging contaminants at a closed and an operating landfill in Oklahoma. Groundwater Monitoring \& Remediation, 32 (1): 120 - 130.

11. Mohamed, F. F., Abdullah, M. P., Othman, M. R. and Zakeria, Z. B. (2012). SPE-LC-Mass spectrometry analysis for basic pharmaceuticals with different therapeutic classes in aquatic environment. Journal of Applied Sciences Research, 8 (4): 2124 - 2132.

12. Al-Qaim, F. F., Abdullah, M. P. and Othman, M. R. (2012). Analysis of different therapeutic classes using liquid chromatography-mass spectrometry in the aquatic environment: a review. International Journal of Pharmacy and Pharmaceutical Science, 4: 3 - 11.

13. Al-Odaini, N. A., Zakaria, M. P., Yaziz, M. I. and Surif, S. (2010). Multi-residue analytical method for human pharmaceuticals and synthetic hormones in river water and sewage effluents by solid-phase extraction and liquid chromatography-tandem mass spectrometry. Journal of Chromatography A, 1217 (44): 6791 - 6806.

14. Miao, X. S. and Metcalfe, C. D. (2003). Determination of cholesterol-lowering statin drugs in aqueous samples using liquid chromatography-electrospray ionization tandem mass spectrometry. Journal of Chromatography A, 998 (1): $133-141$.

15. Jeram Landfill. Access online http://fishguy85.blogspot.my/2012/12/jeram-landfill.html in February 2013.

16. Vieno, N. M., Tuhkanen, T. and Kronberg, L. (2006). Analysis of neutral and basic pharmaceuticals in sewage treatment plants and in recipient rivers using solid phase extraction and liquid chromatography-tandem mass spectrometry detection. Journal of Chromatography A, 1134 (1-2):101 - 111.

17. Drugbank. Open Data Drug and Drug Target Database. Access online http://www.drugbank.ca/ in November 2014. 